\title{
Short- and Long-Distance Moves of Young Adults During the Transition to Adulthood in Britain
}

\author{
Alina Pelikh ${ }^{1}$, Hill Kulu \\ ${ }^{1}$ University of Liverpool, United Kingdom \\ ${ }^{2}$ University of St Andrews, United Kingdom
}

\begin{abstract}
This paper examines spatial mobility of young adults in England and Wales in the 1990s and the 2000s. We investigate short- and long-distance moves of young people by cohort and gender adjusted for individuals' socioeconomic characteristics and changes in other life domains. We study how much employment, partnership and family changes explain variation in spatial mobility across birth cohorts and between males and females. We apply multistate event history analysis to data from the British Household Panel Survey (BHPS). We move beyond a single-event-approach and analyse moving trajectories of young adults. The results show that the youngest cohort (born in 1985-90) leaves the parental home later than the two older cohorts (born in 1974-79 and 1980-84), but once they leave the parental nest, they exhibit elevated levels of spatial mobility. We find that females leave the parental home earlier than males; however, there are no gender differences in the levels of higher-order moves. By contrast, socioeconomic differences in spatial mobility are persistent; young people from advantaged backgrounds are spatially more mobile than those who come from disadvantaged families. Changes in educational enrolment and level, partnership status and economic activity explain only little of the differences in spatial mobility across cohorts and between males and females suggesting also the importance of other motives behind the moves. The results are similar for short- and long-distance moves, although the risk levels are higher for the former than the latter.
\end{abstract}

Keywords: spatial mobility; young adults; transition to adulthood; England and Wales; event history analysis; British Household Panel Survey

\footnotetext{
${ }^{1}$ Correspondence: Alina.Pelikh@liverpool.ac.uk
} 


\section{Introduction}

Leaving the parental home is traditionally considered to be one of the significant markers of the transition to adulthood, together with the formation of a first union, completing education and entry into the labour market (Billari, 2001; Billari \& Liefbroer, 2010; Liefbroer \& Toulemon, 2010; Huinink, 2013). However, in the past few decades, these transitions have become less standardised and more individualised and 'protracted' (Liefbroer, 1999; Shanahan, 2000; Macmillan, 2005; Elzinga \& Liefbroer, 2007; Billari \& Liefbroer, 2010; Huinink, 2013). The expansion of higher education, professionalisation and feminisation of the labour market have led to a variety of trajectories and pathways to social and economic independence. Many young people stay longer in education, and postpone entry into the labour force and union formation (Corijn \& Klijzing, 2001; Billari \& Liefbroer, 2010). Another important recent development is that an increasing number of young people who stay longer in the parental home are forced to move back after graduation (so called 'boomerangs') (Stone, Berrington, \& Falkingham, 2014).

There is a growing body of literature investigating the complexity and variety of transition to adulthood (Holdsworth, 2000; Shanahan, 2000; Berrington, 2001; lacovou, 2002; Settersten \& Ray, 2010; Huinink, 2013). However, residential mobility of young people have not been studied, except moves directly related to leaving the parental home (Goldscheider, Thornton, \& Yang, 2001; Mulder \& Clark, 2000; Hochstenbach \& Boterman, 2017). This paper examines spatial mobility of young people in England and Wales in the 1990s and the 2000s. Our contribution is threefold. First, we analyse moving trajectories instead of one/first move to improve our understanding of the patterns of spatial mobility of young people. We examine changes in spatial mobility by birth cohort (born in 1974-79, 1980-84 and 1985-90) and by gender. Second, we investigate residential changes in relation to changes in other life domains, such as employment, education and partnership histories, which are important determinants of residential changes. Third, we distinguish between short- and long-distance moves to gain a better understanding of how education, employment, and family life shape spatial mobility of young people.

\section{Spatial mobility over the early stage of the life course}

Young people are one of the most mobile group of population in the UK (Duke-Williams, 2009; Champion \& Shuttleworth, 2016a). Young people's migration careers begin once they move out of the parental home. However, many studies have shown that often young people return 
or 'boomerang' to their parental home throughout the early stage of the life course (Da Vanzo \& Goldscheider, 1990; Goldscheider, Thornton, \& Young-DeMarco, 1993; Jones, 1995; Mulder \& Clark, 2002; Sage, Evandrou, \& Falkingham, 2013; Stone et al., 2014). Therefore, the holistic life course approach towards migration careers has become popular in demographic research (Clark, 2013; Clark \& Huang, 2003; Falkingham, Sage, Stone, \& Vlachantoni, 2016; Mulder \& Hooimeijer, 1999; Mulder \& Wagner, 1993). The life course approach suggests that any decision in life, in particular a decision to move or to stay, is connected to other life domains ('linked lives'), such as education and employment careers, partnership and family histories (Giele \& Elder, 1998). Research has also shown that it is important to look at moves as a continuity process, actively involving human agency at all stages of decision-making and the realisation of intentions (Halfacree \& Boyle, 1993; Kley \& Mulder, 2010; Kley, 2011).

\subsection{Leaving the parental home}

There is a large body of literature on 'pathways into independent living' studying the relationships between leaving the parental home and marriage, work or education (Goldscheider \& DaVanzo, 1989; De Jong Gierveld, Liefbroer, \& Beekink, 1991; Berrington \& Murphy, 1994; Holdsworth, 2000; Berrington, 2001; lacovou, 2002; Settersten \& Ray, 2010; Huinink, 2013). Studies also demonstrate that moving decisions are taken under the constraints of welfare state provision, housing policies and family financial support (Cavalli \& Galland, 1995; Jones, 1995; Corijn \& Klijzing, 2001; Cook \& Furstenberg, 2002; Billari, 2004). The decision to move out of the parental home is based on personal preferences, beliefs or aspirations as well as on socially accepted normative timetables for different life stages (Neugarten, Moore, \& Lowe, 1965; Hogan \& Astone, 1986; Holdsworth \& Morgan, 2005; Billari \& Liefbroer, 2007). Research has shown that parental expectations on 'leaving the nest' as well as their willingness and opportunity to support their children in the future have a large effect on the timing and destination of the first move (Whittington \& Peters, 1996; Goldscheider et al., 2001; Settersten \& Ray, 2010; Hochstenbach \& Boterman, 2017).

The British pattern of the transition to adulthood is usually described as 'accelerated' with an early transition from school to work followed by heterogeneous household and family formation (Cavalli \& Galland, 1995; Bynner, 2001). These transitions vary according to class, gender and ethnicity (Coffield, 1995; Bynner, 2001, 2005) with parental socioeconomic resources playing a significant role in the timing and the destination of home leaving. Research shows that young people from advantaged backgrounds leave home earlier for education- 
related reasons than those from disadvantaged families (De Jong Gierveld et al., 1991; Berrington \& Murphy, 1994; Ermisch \& Di Salvo, 1997; Holdsworth, 2000; Berrington, 2001; Furstenberg, 2008; Goldscheider, Hofferth, \& Curtin, 2014). Leaving the parental home for educational reasons is thus an important step towards adulthood and independence among young adults whose parents have tertiary education (De Jong Gierveld et al., 1991; Holdsworth, 2004; Patiniotis \& Holdsworth, 2005). However, leaving the parental home for further studies is not universal and not the only pathway into independent living. The decision to stay in the parental home might be a result of both unaffordability to start living independently as well as personal preferences (Da Vanzo \& Goldscheider, 1990; Patiniotis \& Holdsworth, 2005).

\subsection{Reasons/motives for long- and short-distance moves}

\subsubsection{Mobility 'triggers' and housing adjustments}

Residential changes can be triggered by a number of events, such as changes in occupation, relationships, family and partnership status (Mulder \& Hooimeijer, 1999; Clark \& Huang, 2004; Clark \& Whiters, 2007; Clark, 2013; Falkingham et al., 2016). Finding a job becomes a priority among young people who have recently finished their education regardless of their qualification. Therefore, a change in the economic activity status acts as an important trigger for mobility of young people.

Family changes represent another group of mobility triggers, which may explain spatial mobility among young people. A large body of literature has focused on the effect of life events on mobility, such as entering cohabitation or marriage (Mulder \& Wagner, 1993; Clark \& Huang, 2003), divorce or union dissolution (Feijten \& Van Ham, 2008; Mulder \& Wagner, 2010), childbirth (Kulu, 2008; Kulu \& Milewski, 2008; Michielin \& Mulder, 2008; Kulu \& Steele, 2013) as well on the interrelationships between mobility, employment and family trajectories (Courgeau, 1985; Clark \& Withers, 2009).

Previous research has shown that short-distance moves are normally driven by housing adjustments, whereas long-distance moves are due to changes in employment (Detang-Dessendre \& Molho, 1999; Mulder \& Clark, 2000; Clark \& Huang, 2003; Boyle et al., 2008; Kulu, 2008). However, given the increased diversity of life course transitions, family structure and living arrangements, recent research has shown that such a distinction cannot fully account for the complexity of moving decisions (Clark \& Whiters, 2007; Smith \& Finney, 2015). Bernard, Bell and Charles-Edwards (2016) showed that age profile of short- and long- 
distance moves of young people in Britain are generally similar. Research in the UK, US and Nordic countries has found that a large share of long-distance moves are attributed to reasons other than employment-related (Clark \& Huang, 2004; Lundholm, Garvill, Malmberg, \& Westin, 2004; Clark \& Whiters, 2007; Clark \& Maas, 2012; Coulter \& Scott, 2015).

\subsubsection{Environmental and other reasons for moves}

Environmental factors have also shown to be important when considering young adults' residential mobility. The broad category of those reasons include changing living environment (i.e. moving closer to the nature or to the big city), moving away from the current life situation, moves motivated by personal development (Lundholm et al., 2004; Morrison \& Clark, 2011; Niedomysl, 2011; Vilhelmson \& Thulin, 2016).

Rabe and Taylor (2010) found that neighbourhood qualities influenced the residential mobility of young people in Britain. Research on 'studentification', 'gentrification' and city branding (Duncan and Smith 2006; Smith \& Holt, 2007; Hochstenbach \& Boterman, 2017) has significantly improved our understanding of young people's mobility, suggesting that some moves could be motivated by the search of self-identification and personal development.

The variety of living arrangements among young people, particularly the increased number of shared housing encourages to investigate non-economic aspects of residential mobility. Heath and Clever (2003) found that young people's experiences of shared housing have changed the meaning of home and increased the importance of housemates in the lives of sharers, which directly effects residential mobility. Other factors affecting the decision to move and moving distance include the proximity of peers, relatives and 'parental safety net' (De Jong Gierveld et al., 1991; Michielin, Mulder \& Zorlu, 2008; Sage et al., 2013). The Internet and social media play a significant role in young people's perception of distance by reducing both the transaction costs of a move and the asymmetry of information during the pre-move phase (Dekker \& Engberson, 2014). It has been argued that the Internet use might not be a driving force of migration itself, but rather seen as an 'enabler' or 'catalyst' in spatial mobility (Vilhelmson \& Thulin, 2013; Thulin \& Vilhemson, 2014).

\subsection{Gender differences}

Research shows that females move more often than males (Fielding \& Halford, 1993; Faggian, McCann, \& Sheppard, 2007). One of the main drivers of females' migration behaviour is traditionally considered to be family formation. On average, females enter cohabitation or marriage earlier than males, which for a long time was the single major factor explaining the 
gender gap in the timing of leaving the parental home (Berrington \& Murphy, 1994; Berrington, 2001). Research has shown that residential changes (including the first move) related to entry into marriage are more often short-distance moves (Mulder \& Wagner, 1993; Detang-Dessendre \& Molho, 2000). Research on family migration usually distinguishes between 'tied stayers' and 'tied movers' who are in most cases females following their partners to the location of their new job. This often has negative consequences on their careers (Boyle, Cooke, Halfacree, \& Smith, 2001; Cooke, 2001, 2003; Smits, Mulder, \& Hooimeijer, 2003).

The changing nature of gender-specific education and employment careers over time is also important. Professionalisation and feminisation of the labour market in Britain since the late 1980s increased the share of women who move for educational reasons. Fielding and Halford (1993) found that higher mobility among women is associated with moves between labour markets and may also lead to or be determined by upward social mobility. Boyle and Halfacree (1995) also observed higher mobility among some groups of women among service class, which was mainly attributed to the increase in women's career aspirations. Investigating the patterns in post-studies migration, Faggian et al. (2007) reached to the conclusion that "women use migration as a means of partially compensating for gender differences in the ease of accessing labour markets" (p. 538). Studies also show that dual career households tend to move less due to the complex nexus of career-family decisions (Bailey, Blake, \& Cooke, 2004; Clark \& Withers, 2009).

\subsection{Changes over time}

Various social and economic changes in Britain support both increased and decreased spatial mobility across the cohorts (Champion, \& Shuttleworth, 2016a, 2016b). On the one hand, the expansion of higher education in Britain in the 1990s led to elevated levels of leaving the parental home, but postponed the age of the move as many had to complete A-levels first. Further professionalisation of the labour market has led to a qualification mismatch on the labour market (Chevalier \& Lindley, 2009) and forced young adults to move to more attractive labour market areas, e.g. 'escalator regions' in the South East of England (Fielding, 1992; Smith \& Holt, 2007; Faggian \& McCann, 2009; Smith \& Sage, 2014). During the recent decades cohabitation and 'living-apart-together' relationships have become more common among young adults, whereas the direct marriage rates have significantly declined alongside the increase in the age at marriage (Ermisch \& Francesconi, 2000; Haskey, 2005; Sobotka \& 
Toulemon, 2008; Ermisch \& Siedler, 2009). The increase in cohabitation, separation and repartnering levels suggests that young people move more often to adjust their housing conditions to changing partnership statuses; all these changes might lead to the increase in spatial mobility (Thomson, 2014; Hannemann \& Kulu, 2015; Mikolai \& Kulu, 2017).

By contrast, unaffordability of housing, introduction of tuition fees and the subsequent economic hardship could be obstacles on the way of gaining independence for some groups of young adults. The residualisation of the social housing sector and increased barriers to home ownership led to the increase in the private renting sector and change of living arrangements among young people (Clapham, Mackie, Orford, Thomas, \& Buckley, 2014; Berrington \& Stone, 2014). The introduction of tuition fees in 1998 and their subsequent increase has raised the levels of student debt, which may be a barrier to financial and residential independence of young people (Stone, Berrington, \& Falkingham, 2011). Hence, many young people tend to stay in their parental home longer or move back after graduation (Ibid., 2011). The increase of dual career households and 'living-apart-together' (LAT) relationships could lead to the decrease in 'tied' female migration and postponement of family formation and thus reduce spatial mobility (Cooke, 2001).

Another factor affecting young peoples' mobility trajectories is the type of residential context. High prices and tight housing markets in big cities especially in London can be an obstacle for young people intending to change their living arrangements (Clark \& Huang, 2004), including leaving the parental home (Higher Education Funding Council for England 2009). The general postponement of marriage and childbearing in London (Kulu \& Washbrook, 2014) together with a large proportion of young singles living in shared housing might be another reason for the lower residential mobility.

During the last few decades, socioeconomic and cultural changes, particularly expansion of higher education and professionalisation and feminisation of the labour market, have led to increased difficulties in decision-making especially in the early stage of the life course (Francesconi \& Golsch; 2003; Furlong \& Cartmel, 2007; Liefbroer, 1999; Mills \& Blossfeld, 2003). These changes have led to the increased divergence in life careers between young people from more advantaged and disadvantaged backgrounds and prompted the emergence of a variety of living arrangements, individualisation of migration and family trajectories, and pathways to social and economic independence (Elzinga \& Liefbroer, 2007; Huinink, 2013; Macmillan, 2005). This may have increased polarisation among young adults by migration 
trajectories; those who prolong staying in the parental home due to economic reasons or personal preferences and those whose migration careers begin earlier and are less stuctured. The increased individualisation of the life course is also reflected in the increased importance of environmental and personal motives behind the decision to move among young people.

\subsection{Hypotheses}

As our literature review shows, a decision to move is motivated by two groups of factors. The first group includes life course events, such as changes in occupation, family and partnership status. The second group includes reasons, which are harder to measure, such as environmental factors, neighbourhood preferences, importance of proximity of friends and parents, and search for a better quality of life. Various societal changes support both increased and decreased mobility among young people. Based on previous research we first expect to observe the postponement of leaving the parental home among the youngest cohort (H1). However, we do not expect lower overall spatial mobility among this cohort. Hence, an interesting question is how much polarisation in migration behaviour we will observe among young adults in Britain. Second, we expect young women to show higher spatial mobility than men (H2). Third, we expect young people from more advantaged socioeconomic backgrounds to leave the parental home earlier than those who come from disadvantaged families (H3). Fourth, we expect young people in London to leave the parental home later and show lower spatial mobility later than those living outside of London ( $\mathrm{H} 4)$. Fifth, we expect similar patterns for short- and long-distance moves among young adults, although the risk levels are higher for the former type of moves than the latter (H5). Finally, we expect changes in educational enrolment and level, partnership status and economic activity to explain some of the cohort and gender differences in long- and short-distance moves (H6). However, an interesting question is how much variation in spatial mobility across birth cohorts and between males and females is left after accounting for changes in these life domains.

\section{Data, variables and method}

\subsection{Sample}

The British Household Panel Survey (BHPS) is an annual panel survey consisting of a nationally representative sample of about 5,500 households recruited in 1991, containing a total of approximately 10,000 individuals. The BHPS provides a good opportunity to investigate spatial mobility and other life course trajectories of young people. It contains detailed annual information about residential and housing changes, educational and employment changes, 
union formation and dissolution, and the birth of children. Respondents are also asked to provide the year and month of a move. However, short-term temporary changes in living arrangements between the waves cannot be identified because only one move per wave is reported. The place of residence is recorded at each panel; we use information on the local authority districts (LAD) of the respondents' place of residence. LAD is a generic term used to cover London boroughs, metropolitan districts, unitary authorities and non-metropolitan districts in England; unitary authorities in Wales; council areas in Scotland; and district council areas in Northern Ireland (ONS, 2016). Our sample includes data from 274 LADs.

Because information on the moves was collected at each panel wave (and not retrospectively), we followed only persons who reached the age of 16 between 1991 and 2006 in England and Wales, for whom the data was collected prospectively. Only respondents present at least two consecutive waves were included.

The final sample contains 2,562 individuals from three birth cohorts: 1974-79, 1980-84 and 1985-90, observed over the period of 1991-2008. We observed individuals from age 16 and followed them until their last interview date. Calculating panel attrition for such samples is not straightforward (Stone et al., 2014). We calculated the proportion of individuals who participated at least in five waves or more (not necessarily subsequently). According to this approach, $90 \%$ of respondents in the 1974-79 cohort participated on average in at least in five waves; these proportions are $83 \%$ for the $1980-84$ cohort; and $80 \%$ for the youngest $1985-89$ cohort. The dataset has a few other limitations, e.g. temporary migration out of Britain ('gap year' or exchange studies abroad, including a move to Northern Ireland) was coded in the same way as a missing wave due to other reasons; the reasons of moving have not been recorded explicitly; for many cases answers are missing.

During the data preparation, we had to address the issue of missing months for major events, such as moves or changes in employment, education and partnership status. In order to minimise the error we assumed events with missing month to happen in July. Life events that were reported in the same month were ordered in the following way: union dissolution (beginning of the month - 0) - change in employment and education spell (middle of the month $-1 / 2)$ - move $\left(7 / 12\right.$ of the month) - cohabitation ( $2 / 3$ of the month). ${ }^{2}$

\footnotetext{
${ }^{2}$ Additionally, sensitivity analysis showed that coefficients for the order and type of move, cohort, gender, parental SES and residential context did not change regardless of whether we had assigned the move to $1 / 3,7 / 12$ or $7 / 8$ of the month.
} 


\subsection{Variables}

\section{Distance of move}

We distinguished between short- and long-distance moves. There are two ways of defining short- and long-distance moves. The first method uses the distance of move, and normally defines a move of more than $50 \mathrm{~km}$ as a long-distance move (Boyle, 1995; Boyle, Cooke, Halfacree, \& Smith, 2001; Clark \& Huang, 2004; Champion \& Shuttleworth, 2016a). Another way is to use functional labour market areas to distinguish between moves within and between labour market areas as short- and long-distance moves, respectively (Clark \& Huang, 2003; Kulu \& Washbrook, 2014).

In this study, a move is considered to be short-distance if it occurred within a labour market area (LMA), and long-distance if an individual moved to a different LMA. The advantage of this approach over the distance-based approach is that it distinguishes better the moves within the individuals' daily 'activity spaces' from those between them. A LMA consists of an urban centre and the surrounding local authority areas, if at least $15 \%$ of the area's employed population commuted to the urban centre in 2001. The areas were created by using 2001 Census commuting flow data. ${ }^{3}$ Our sample covers information from 218 labour market areas in Britain, with the London region made up of 33 smaller local districts. The ways of defining urban thresholds are widely discussed in migration literature (Coombes, 2000; Hugo, Champion, \& Lattes, 2003). Kulu and Washbrook (2014) showed a high consistency of fertility levels by applying $15 \%, 20 \%$ and $30 \%$ thresholds.

\section{Order of move}

We distinguished between first moves (leaving the parental home), second moves and higher order moves.

\section{Parental socioeconomic status}

Parental occupational class was used to control for socioeconomic background. The panel contains information on respondent's mother's and father's occupational status, which is available from the household grid. We used data from the wave where respondents became 16. In case the occupational class of the mother and the father was different, priority was given to the information about the father's occupational status. The categories were coded

\footnotetext{
${ }^{3}$ The current ONS criteria for defining Travel to Work Areas (TTWAs) is that generally at least $75 \%$ of an area's resident workforce work in the area and at least $75 \%$ of the people who work in the area also live in the area.
} 
using the Goldthorpe social class schema, distinguishing between service, intermediate and working class (Goldthorpe, Llewellyn, \& Payne, 1980; Goldthorpe, 1983).

\section{Educational level}

The minimum school-leaving age in Britain for all individuals in our sample was 16 years. The variable is based on the self-reported question about the highest qualification degree obtained at the time of the interview and is therefore time-varying. We specified three levels for this covariate: (1) compulsory school education (GCSE or equivalent); (2) post-compulsory education ("A-levels", "Higher National Certificate (HNC) or Diploma (HND)", "Teaching qualifications" and other professional certificates); (3) bachelor's degree or higher ("Higher Degree" and "1 1 st Degree" categories).

\section{Partnership status}

Information on partnership histories is available both from the panel and from the marital and union histories which were collected additionally in waves 2, 11 and 12, respectively (Pronzato, 2010). The dataset contains information on the type of union (cohabitation or marriage), starting and ending date of the union and how the union ended (divorce or widowhood if were married; separation or marriage if were cohabitating).

\section{Additional control variables}

We additionally controlled for a time-varying economic activity status which included categories: (1) working full-time; (2) working part-time; (3) full-time students; (4) unemployed; (5) others or missing. We also accounted for the area type of residence, distinguishing between London, other urban areas, and towns and rural areas.

\subsection{Method}

We used multistate event history analysis to examine spatial mobility of young adults. Each individual in the sample is at the risk of moving several times. Moves are treated as repeated events and we distinguish between short- and long-distance moves, treating them as competing events. This approach has proved to be a powerful tool for investigating complex moving trajectories (Kulu, 2008; Kulu \& Steele, 2013). We specify a piecewise constant exponential model, which can be formalised as follows:

$$
\begin{aligned}
& \ln \mu_{i m}^{S D}(t)=\ln \mu_{0}^{S D}(t)+\sum_{k} \alpha_{k}^{S D} x_{i m k}+\sum_{j} \beta_{j}^{S D} w_{i m j}(t)+\varepsilon_{i}^{S D}, \\
& \ln \mu_{i m}^{L D}(t)=\ln \mu_{0}^{L D}(t)+\sum_{k} \alpha_{k}^{L D} x_{i m k}+\sum_{j} \beta_{j}^{L D} w_{i m j}(t)+\varepsilon_{i}^{L D}
\end{aligned}
$$


where $\mu_{i m}^{S D}(t)$ and $\mu_{i m}^{L D}(t)$ denote the risk of the $m$ th short(SD)- and long(LD)-distance move for individual $i, \mu_{0}(t)$ denotes a piecewise constant age baseline (age or time since previous move for second and higher order moves), $x_{k}$ represents time-constant variables and $w_{j}(t)$ represents time-varying variables. Since residential episodes are nested within individuals, an individual-level error term $\varepsilon_{i}$ was added to the equation to control for the clustering and unobserved determinants of residential changes (Cleves, Gutierrez, William, \& Marchenko, 2010; Putter, Fiocco, \& Geskus, 2007).

First, we analyse the hazard of moving by the order of move, cohort and gender. We then include the covariates and fit separate models for all, first, second, and higher order moves to further investigate whether there are differences by cohort and gender in spatial mobility patterns throughout the early stage of the life course. Next, we fit models with threeway interactions between cohort or gender, order and distance of move to investigate whether the trends in short- and long-distance moves differ from each other. We compare the results for the interaction models, containing all time-varying covariates to those with only fixed covariates to investigate how much the changes in educational enrolment and level, partnership status and economic activity account for in spatial mobility across birth cohorts and between men and women.

\section{Results}

First, we analyse the risk of a move among all cohorts. Table 1 provides information on the number of events (moves), number of person-years, hazard rates, and the median age at move by order of moves. In our sample, $50 \%$ of respondents have left the parental home by age 22 . A half of those who left home moved for the second time within approximately 2 years. The annual rate of moves for the sample is 189 moves per 1,000 person-years. The rates for the second and higher order moves are higher than that of first moves.

\section{(Table 1)}

Table 2 provides an overview on the median age at first move by cohort and gender. The median age of leaving the parental home among the youngest cohort is approximately one year higher than for the other two cohorts (22.5 years for the 1985-1990 cohort, 21.4 and 21.6 for the 1974-1979 and 1980-1984 cohorts respectively). The question arises as to whether this signals the postponement of moves or rather is a marker of reduced mobility (or eventually 
both). Among all cohorts, females leave the parental home earlier than males. Together with the general postponement of first moves, the gender gap increased from 1.2 to 2 years between the cohorts 1974-79 and 1985-90.

(Table 2)

Next we analysed the hazard rates for all moves and by order of moves for each cohort. Figure 1 shows that the hazard rates for all moves decrease across cohorts. Rates for the youngest cohort are significantly lower for all and for first moves, which supports the postponement of moves among the youngest cohort. However, the analysis also demonstrates that spatial mobility levels among those who left home is higher for the youngest cohort than for the two older cohorts.

(Figure 1)

In order to investigate cohort and gender differences in spatial mobility, we fitted separate models with a three-way interaction term between distance, order of move, and cohort or gender. Figure 2 provides relative hazard rates of first, second and higher order short- and long-distance moves by cohort. Young adults from all three cohorts are more likely to move short than long distance, as expected (e.g. Mulder \& Clark, 2000). However, for the first moves the differences in mobility levels by distance of move are the smallest, suggesting that an increasing number of young adults are long-distance home-leavers. A tendency (although not statistically significant) towards higher order mobility among the youngest cohort can be attributed mostly to short-distance moves.

(Figure 2)

Figure 3 shows the intensity of moves throughout the early stage of the life course separately for males and females. Females from all cohorts move out of the parental home earlier than males, both for short- and long-distances. The majority of moves are short-distance among both males and females. For higher order moves $\left(3^{\text {rd }}+\right)$ gender differences in the risk of a move disappear both in short- and long-distance moves.

(Figure 3)

Figure 4 shows the results for the standardisation of first moves by educational level, partnership status and economic activity. By including education, employment and partnership as time-varying covariates into the model we account both for the influence of a status change (event-'trigger') as well as for the differences in mobility levels depending on current 
education, partnership status and economic activity. For instance, moves due to the change of educational level from 'post-compulsory' to a 'degree' level (meaning finishing education and moving) as well as moves of highly educated persons will appear in the model under the same category. However, we believe that this ways of measurement will not bias the analysis, as the main question is whether the cohort and gender differences persist after adjusting for compositional factors. Future research could explicitly distinguish between variation 'within individuals' and 'between individuals'. ${ }^{4}$ After including control variables into the model, the coefficients only slightly changed. This suggests that little (if any) of the cohort differences in mobility can be explained by the changes in educational enrolment and level, partnership status and economic activity. Figure 7A in the Appendix illustrates the same analysis for second and higher order short-distance moves supporting the findings for the first moves.

(Figure 4)

Figure 5 shows that gender differences in first moves persist after controlling for all timevarying covariates of interest for both types of moves. They are significant across all three cohorts in short- and long-distance moves. Figure $6 \mathrm{~A}$ in the Appendix shows the effects of partnership status and educational level on hazards for the second and higher order shortdistance moves as they show some fluctuation compared to the long-distance moves. Gender differences in second moves became slightly larger after controlling for partnership status, but its inclusion has little impact on third and higher order moves. After controlling for educational level, the coefficients for both males and females decreased and became insignificant. Therefore, it can be concluded that both cohort and gender differences in short- and longdistance moves showed only little changes after controlling for all covariates of interest.

(Figure 5)

\footnotetext{
${ }^{4}$ In line with the order of life events which we ascribed to the simultaneous events (described in the section 3.1), moves of individuals with the reported partnership status "cohabiting" refer to the moves of those already living together with their partner, whereas moves of those who start living with a partner (and therefore the move happens at the same time as the cohabitation spell begins) would fall under the moves of single or separated (depending on the union order). The coefficients are especially sensitive in the models for the first moves, as the category "cohabiting" and "married" include a few cases when individuals started living together under their parents' roofs and therefore were more prone to move out. The coefficients for the economic activity status should be interpreted following the same logic. For example, moves of unemployed individuals are related to both moves of unemployed and moves due to becoming unemployed.
} 
Finally, Table 3 contains information on the effect of control variables. As expected, young people from advantaged socioeconomic background leave the parental home earlier than those who come from disadvantaged families. Young people from the two older cohorts who were living in London at age 16 left the parental home later than their counterparts outside of London. For the risk of a higher order of move, the differences between London and the rest of the country became less pronounced for all cohorts. There were no geographical differences for the youngest cohort.

(Table 3)

\section{Conclusion and discussion}

In this paper we analysed order-specific moves of young people in Britain during the transition to adulthood. We investigated cohort and gender differences in short- and long-distance moves among young adults since age 16 . The analysis of spatial mobility by cohort supported our hypothesis on the low risk of a first move among the youngest cohort (H1). We found evidence for the postponement of leaving the parental home among the youngest cohort by approximately a year compared to the older cohorts, supporting the overall trends towards 'protracted' youth transitions (Liefbroer, 1999; Billari \& Liefbroer, 2010). Despite the observed general decline in mobility, we found a tendancy towards higher levels of second and higher order moves among the youngest cohort. The results for both short- and long-distance moves showed that changes in educational enrolment and level, partnership status and economic activity explained little (if any) of the differences in spatial mobility across cohorts (H6), which suggests the increasing importance of other motives behind the moves of young people (e.g. environmental and social reasons, personal preferences, family ties and cultural norms). The tendency towards elevated levels of second and higher order moves among the youngest cohort may provide support for the growing polarisation between the 'stayers' (those who prolong staying in the parental home) and the 'movers' (those who move out and show a relatively high mobility rate). This observation is in line with previous findings of higher spatial mobility among those who moved at least once (repeat-movers) (Clark and Huang, 2004; Clark and Whithers, 2007).

Our analysis of gender differences in spatial mobility among young people supported that females leave the parental home earlier than males among all cohorts $(\mathrm{H} 2)$. It is likely that some of these gender differences are due to females' earlier entry into partnership as well as a reflection of the reverse gender gap in education observed in Britian since the beginning of the 
1990s. After controlling for partnership status and educational level, gender differences in first moves still persisted, but they disappeared for higher order moves. This finding contradicts our expectation ( $\mathrm{H} 2)$ on women's higher mobility during the transition to adulthood. The convergence of mobility patterns by gender supports the tendency towards similarity in life transitions among young people (Winkler-Dworak \& Toulemon, 2007; Stone et al., 2014), resulting from a longstanding process of the changing role of women in British society (Falkingham et al., 2016).

Our analysis supports that young adults from more advantaged socioeconomic backgrounds leave the parental nest earlier among all cohorts $(\mathrm{H} 3)$. The polarisation by spatial mobility observed among young adults contributes to the general discussion of the increased divergence in life careers between young people from more advantaged and disadvantaged backgrounds in Britain (Coffield, 1995; Berrington, 2001; Bynner, 2001, 2005; Ekert-Jaffe, Joshi, Lynch, Mougin, \& Rendall, 2002; Stone et al., 2011). The analysis also supported the hypothesis regarding later leaving of the parental home among Londoners for all cohorts, although, we did not find any evidence for lower mobility in London compared to other urban areas (H4). Overall, the results were similar for short- and long-distance moves, although the risk levels were higher for the former than the latter (H5).

In this paper we mostly analysed cohort and gender differences, by considering the influence of changes in other life domains, namely education, employment and partnership careers. We found that the youngest cohort postpones leaving the parental home, but there is a tendency towards elevated levels of second and further moves, which might be a sign of polarisation in spatial mobility. We found that females leave the parental home earlier than males, but afterwards the patterns in spatial mobility among males and females converge. Further research is needed to determine to what extent the polarisation among cohorts, if true, is driven by the increased economic precarity among young people (high tuition fees, lower level of labour market security and limited affordability of housing) or by other factors. A more detailed analysis of the effects of each transition in education, employment and partnership careers might provide further insights into the spatial mobility patterns among young people. Another question remains as to whether the convergence of gender mobility patterns could also be a result of self-selection among the more mobile young people.

Research on young adults' complex transitions and changing values further supports the idea of thinking beyond the simple economic rationality behind the moves, which might as well 
contribute to our understanding of mobility polarisation. After controlling for the effects of some of the migration events-triggers, such as changes in employment, relationships and family size, the cohort differences in spatial mobility persisted, suggesting the importance of other factors. These motives include among others changing living environment, neighbourhood quality and specific preferences, personal development, proximity to the parental home and peers (living in shared housing) as well as other family ties. The concept of 'lifestyle migration' (Walford \& Stockdale, 2015) and the 'new mobility paradigm' (Sheller \& Urry, 2006) propose further meaning of movements as an active practice rather than simply the goal-oriented adjustment process and therefore might be seen as an alternative explanation for young people's movements. Further research is needed to investigate the reasons behind the increased mobility of 'movers' and investigate as to whether this is a sign of establishment of a new 'social norm' in mobility linked to the 'age of migration' and transformed cultural meaning of shared housing or whether this is driven mostly by the environmental and social factors.

Applying multistate models to longitudinal data from Britain, this study showed significant differences in spatial mobility among young adults by birth cohort, gender and socioeconomic background. The future research should combine individual histories from the BSPS and the Understanding Society study (UoS) to study life histories of the youngest cohort; and also apply qualitative methods. Further the suggested approach could be applied to data from other industrialised countries to improve our understanding of how much changes in educational level, partnership and economic activity status explain changes in spatial mobility and reasons for moving among young people in industrialised countries. Given the increased cross-national heterogeneity in the timing and sequencing of events during the transition to adulthood an important question is whether spatial mobility patterns among young adult increasingly vary across countries.

\section{References}

Bailey, A. J., Blake, M. K., \& Cooke, T. J. (2004). Migration, care, and the linked lives of dualearner households. Environment and Planning A, 36(9), 1617-1632.

Bernard, A., Bell, M., \& Charles-Edwards, E. (2016). Internal migration age patterns and the transition to adulthood: Australia and Great Britain compared. Journal of Population Research, 33, 123-146.

Berrington, A. (2001). Transition to adulthood in Britain. In M. Corijn \& E. Klijzing (Eds.), Transitions to adulthood in Europe (pp. 67-102). Dordrecht/Boston/London: Kluwer Academic Publishers. 
Berrington, A., \& Murphy, M. (1994). Changes in the living arrangements of young adults in Britain during the 1980s. European Sociological review, 10(3), 235-257.

Billari, F. (2001). The analysis of early life courses: Complex descriptions of the transition to adulthood. Journal of Population Research, 18(2), 119-142.

Billari, F. (2004). Becoming an adult in Europe: A macro (/micro)-demographic perspective. Demographic Research, 3, 15-44.

Billari, F., \& Liefbroer, A. (2007). Should I stay or should I go? The impact of age norms on leaving home. Demography, 44(1), 181-198.

Billari, F., \& Liefbroer, A. (2010). Towards a new pattern of transition to adulthood? Advances in life course research, 15(2-3), 59-75.

Boyle, P. (1995). Public housing as a barrier to long-distance migration. International Journal of Population Geography, 1(2), 147-164.

Boyle, P., Cooke, T. J., Halfacree, K., \& Smith, D. (2001). A cross-national comparison of the impact of family migration on women's employment status. Demography, 38(2), 201213.

Boyle, P. J., \& Halfacree, K. H. (1995). Service class migration in England and Wales, 19801981: identifying gender-specific mobility patterns. Regional studies, 29(1), 43-57.

Boyle, P. J., Kulu, H., Cooke, T., Gayle, V., \& Mulder, C. H. (2008). Moving and union dissolution. Demography, 45(1), 209-222.

Bynner, J. (2001). British youth transitions in comparative perspective. Journal of youth studies, 4(1), 5-23.

Bynner, J. (2005). Rethinking the youth phase of the life-course: The case for emerging adulthood? Journal of youth studies, 8(4), 367-384.

Cavalli, A., \& Galland, O. (1995). Youth in Europe. London/ New York: Pinter.

Champion, A. C., \& I. Shuttleworth, I. (2016a). Are people changing address less? An analysis of migration within England and Wales, 1971-2011, by distance of move, Population, Space and Place.

Champion, A. C., \& I. Shuttleworth, I. (2016b). Is longer-distance migration slowing? An analysis of the annual record for England and Wales since the 1970s, Population, Space and Place.

Chevalier, A., \& Lindley, J. (2009). Overeducation and the skills of UK graduates. Journal of the Royal Statistical Society: Series A, 172(2), 307-337.

Clapham, D., Mackie, P., Orford, S., Thomas, I., \& Buckley, K. (2014). The housing pathways of young people in the UK. Environment and Planning A, 46, $2016-2031$.

Clark, W. (2013). Life course events and residential change: unpacking age effects on the probability of moving. Journal of Population Research, 30(4), 319-334.

Clark, W. A., \& Huang, Y. (2003). The life course and residential mobility in British housing markets. Environment and Planning A, 35(2), 323-339.

Clark, W., \& Huang, Y. (2004). Linking migration and mobility: individual and contextual effects in housing markets in the UK. Regional studies, 38(6), 617-628.

Clark, W., \& Whiters, S. (2007). Family migration and mobility sequences in the United States: Spatial mobility in the context of the life course. Demographic Research, 17(20), 591622.

Clark, W. A., \& Withers, S. D. (2009). Fertility, mobility and labour-force participation: A study of synchronicity. Population, space and place, 15(4), 305-321.

Clark, W. A., \& Maas, R. (2012). Interpreting migration through the prism of reasons for moves: What can we learn about the economic returns to migration from survey data. California Center for Population Research Online Working Paper Series.

Cleves, M., Gutierrez, R. G., William, G., \& Marchenko, Y. V. (2010). An introduction to survival analysis using Stata (3rd ed.). Texas: Stata Press. 
Coffield, F. (1995). Always the Trainee, Never the Employee? Increasingly protracted transitions in the UK. In A. Cavalli \& O. Galland (Eds.), Youth in Europe. (pp. 45-62). London/New York: Pinter.

Cook, T., \& Furstenberg, F. (2002). Explaining aspects of the transition to adulthood in Italy, Sweden, Germany, and the United States: A cross-disciplinary, case synthesis approach. The Annals of the American Academy of Political and Social Science, 580(1), 257-287.

Cooke, T. J. (2001). 'Trailing wife'or 'trailing mother'? The effect of parental status on the relationship between family migration and the labor-market participation of married women. Environment and Planning A, 33(3), 419-430.

Cooke, T. J. (2003). Family migration and the relative earnings of husbands and wives. Annals of the Association of American Geographers, 93(2), 338-349.

Coombes, M. (2000). Defining locality boundaries with synthetic data. Environment and Planning A, 32(8), 1499-1518.

Corijn, M., \& Klijzing, E. (2001). Transitions to adulthood in Europe. Dordrecht: Kluwer Academic Publishers.

Coulter, R., \& Scott, J. (2015). What Motivates Residential Mobility? Re-examining Self-Reported Reasons for Desiring and Making Residential Moves. Population, space and place, 21(4), 354-371.

Courgeau, D. (1985). Interaction between spatial mobility, family and career life-cycle: a French survey. European sociological review, 1(2), 139-162.

Da Vanzo, J., \& Goldscheider, F. K. (1990). Coming home again: Returns to the parental home of young adults. Population Studies, 44(2), 241-255.

De Jong Gierveld, J., Liefbroer, A. C., \& Beekink, E. (1991). The effect of parental resources on patterns of leaving home among young adults in the Netherlands. European sociological review, 7(1), 55-71.

Dekker, R., \& Endbersen, G. (2014). How social media transform migrant networks and facilitate migration. Global Networks, 14(4), 401-418.

Detang-Dessendre, C., \& Molho, I. (1999). Migration and changing employment status: a hazard function analysis. Journal of Regional Science, 39(1), 103-123.

Detang-Dessendre, C., \& Molho, I. (2000). Residence spells and migration: a comparison for men and women. Urban studies, 37(2), 247-260.

Duke-Williams, O. (2009). The Geographies of Student Migration in the UK. Environment and Planning A, 41, 1826-1848.

Duncan, S., \& Smith, D. (2006). Individualisation versus the geography of 'new' families. Twenty-First Century Society, 1(2), 167-189.

Ekert-Jaffé, O., Joshi, H., Lynch, K., Mougin, R., \& Rendall, M. (2002). Fertility, timing of births and socio-economic status in France and Britain. Population, 57(3), 475-507.

Elzinga, C. H., \& Liefbroer, A. C. (2007). De-standardization of family-life trajectories of young adults: A cross-national comparison using sequence analysis. European Journal of Population/Revue européenne de Démographie, 23(3-4), 225-250.

Ermisch, J., \& Di Salvo, P. (1997). The economic determinants of young people's household formation. Economica, 64(256), 627-644.

Ermisch, J., \& Francesconi, M. (2000). Cohabitation in Great Britain: not for long, but here to stay. Journal of the Royal Statistical Society: Series A (Statistics in Society), 163(2), 153171.

Ermisch, J., \& Siedler, T. (2009). Living Apart Together. In M. Brynin \& J. Ermisch (Eds.), Changing relationships (pp. 29-43). New York; Oxon: Routledge. 
Faggian, A., McCann. P., \& Sheppard, S. (2007). Some evidence than women are mobile than men: gender differences in U.K. graduate migration behavior. Journal of Regional Sciences, 47(3), 517-539.

Faggian, A., \& McCann, P. (2009). Human capital, graduate migration and innovation in British regions. Cambridge Journal of Economics, 33(2), 317-333.

Falkingham, J., Sage, J., Stone, J., \& Vlachantoni, A. (2016). Residential mobility across the life course: continuity and change across three cohorts in Britain. Advances in life course research.

Feijten, P., \& Van Ham, M. (2008). Residential mobility and migration of the divorced and separated. Demographic Research, 17, 623-653.

Fielding, A., \& Halford, S. (1993). Geographies of opportunity: a regional analysis of genderspecific social and spatial mobilities in England and Wales, 1971-81. Environment and Planning A, 25(10), 1421-1440.

Fielding, A. J. (1992). Migration and social mobility: South East England as an escalator region. Regional studies, 26(1), 1-15.

Francesconi M, \& Golsch, K. (2005). The Process of Globalisation and Transitions to Adulthood in Britain. In H.-P. Blossfeld, E. Klijzing, M. Mills, K. Kurz (Eds.), Globalization, Uncertainty and Youth in Society (pp.249-276). London/ New York: Routledge.

Furlong, A., \& Cartmel, F. (2007). Young people and social change: New perspectives (2nd ed.). Berkshire: Open University Press/McGraw Hill.

Furstenberg, F. (2008). The intersections of social class and the transition to adulthood. New directions for child and adolescent development, 2008(119), 1-10.

Geist, C., \& McManus, P. A. (2012). Different reasons, different results: Implications of migration by gender and family status. Demography, 49(1), 197-217.

Giele, J. Z., \& Elder, G. H. (1998). Methods of lifecourse research: Qualitative and quantitative approaches. Thousand Oaks: Sage Publications.

Goldscheider, F., Thornton, A., \& Yang, L. S. (2001). Helping out the kids: Expectations about parental support in young adulthood. Journal of Marriage and Family, 63(3), 727-740.

Goldscheider, F., Thornton, A., \& Young-DeMarco, L. (1993). A portrait of the nest-leaving process in early adulthood. Demography, 30(4), 683-699.

Goldscheider, F. K., \& DaVanzo, J. (1989). Pathways to independent living in early adulthood: Marriage, semiautonomy, and premarital residential independence. Demography, 26(4), 597-614.

Goldscheider, F. K., Hofferth, S. L., \& Curtin, S. C. (2014). Parenthood and leaving home in young adulthood. Population research and policy review, 33(6), 771-796.

Goldthorpe, J. H. (1983). Women and class analysis: in defence of the conventional view. Sociology, 17(4), 465-488.

Goldthorpe, J. H., Llewellyn, C., \& Payne, C. (1980). Social Mobility and Class Structure in Modern Britain. Oxford: Clarendon Press.

Halfacree, K.H., \& Boyle, P.J. (1993). The challenge facing migration research: the case for a biological approach. Progress in Human Geography, 17(3), 333-348.

Hannemann, T., \& Kulu, H. (2015). Union formation and dissolution among immigrants and their descendants in the United Kingdom. Demographic Research, 33, 273-312.

Haskey, J. (2005). Living arrangements in contemporary Britain: Having a partner who usually lives elsewhere and Living Apart Together (LAT). Population Trends, 122, 35-45.

Heath, S., \& Cleaver, E. (2003). Young, free and single? Twenty-somethings and household change. Basingstoke: Palgrave Macmillan.

Higher Education Funding Council for England (2009). Patterns in higher education: Living at home. 9/20. 
Hochstenbach, C., \& Boterman, W. R. (2017). Intergenerational support shaping residential trajectories: Young people leaving home in a gentrifying city. Urban studies, 54(2), 399420.

Hogan, D. P., \& Astone, N. M. (1986). The transition to adulthood. Annual review of sociology, $12,109-130$.

Holdsworth, C. (2000). Leaving home in Britain and Spain. European sociological review, 16(2), 201-222.

Holdsworth, C. (2004). Family support during the transition out of the parental home in Britain, Spain and Norway. Sociology, 38(5), 909-926.

Holdsworth, C., \& Morgan, D. (2005). Transitions In Context: Leaving Home, Independence And Adulthood: Leaving home, independence and adulthood. Berkshire: Open Universitz Press/McGraw-Hill Education.

Hugo, G., Champion, A., \& Lattes, A. (2003). Toward a new conceptualization of settlements for demography. Population and Development Review, 29(2), 277-297.

Huinink, J. (2013). De-standardisation or changing life course patterns? Transition to adulthood from a demographic perspective The Demography of Europe (pp. 99-118): Springer.

lacovou, M. (2002). Regional differences in the transition to adulthood. The Annals of the American Academy of Political and Social Science, 580(1), 40-69.

Jones, G. (1995). Leaving home. Buckingham: Open University Press.

Kley, S. (2011). Explaining the Stages of Migration with a Life-course Framework. European Sociological Review, 27(4), 469-486.

Kley, S. A., \& Mulder, C. H. (2010). Considering, planning, and realizing migration in early adulthood. The influence of life-course events and perceived opportunities on leaving the city in Germany. Journal of Housing and the Built Environment, 25(1), 73-94.

Kulu, H. (2008). Fertility and spatial mobility in the life course: evidence from Austria. Environment and Planning A, 40(3), 632-652.

Kulu, H., \& Milewski, N. (2008). Family change and migration in the life course: An introduction. Demographic Research, 17, 567-590.

Kulu, H., \& Steele, F. (2013). Interrelationships between childbearing and housing transitions in the family life course. Demography, 50(5), 1687-1714.

Kulu, H., \& Washbrook, E. (2014). Residential context, migration and fertility in a modern urban society. Advances in life course research, 21, 168-182.

Liefbroer, A. C. (1999). From youth to adulthood: Understanding changing patterns of family formation from a life course perspective. In L. Van Wissen \& P. Dykstra (Eds.), Population Issues (pp. 53-85): Springer.

Liefbroer, A. C., \& Toulemon, L. (2010). Demographic perspectives on the transition to adulthood: An introduction. Advances in life course research, 15(2), 53-58.

Lundholm, E., Garvill, J., Malmberg, G., \& Westin, K. (2004). Forced or free movers? The motives, voluntariness and selectivity of interregional migration in the Nordic countries. Population, space and place, 10(1), 59-72.

Macmillan, R. (2005). The structure of the life course: Classic issues and current controversies. Advances in life course research, 9, 3-24.

Michielin, F., \& Mulder, C. H. (2008). Family events and the residential mobility of couples. Environment and Planning A, 40(11), 2770-2790.

Michielin, F., Mulder, C., \& Zorlu, A. (2008). Distance to Parents and Geographical Mobility. Population, Space and Place, 14(4), 327-345.

Mikolai, J. \& Kulu, H. (Forthcoming) Short- and long-term effects of divorce and separation on housing tenure in England and Wales. Population Studies.

Mills, M., \& Blossfeld, H.-P. (2003). Globalization, uncertainty and changes in early lifecourses. Zeitschrift für Erziehungswissenschaft, 6(2), 188-218. 
Morrison, P. S., \& Clark, W. A. V. (2011). Internal migration and employment: macro flows and micro motives. Environment and Planning A, 43, 1978-1964.

Mulder, C. H., \& Clark, W. A. (2000). Leaving home and leaving the state: Evidence from the United States. International Journal of Population Geography, 6(6), 423-437.

Mulder, C. H., \& Clark, W. A. (2002). Leaving home for college and gaining independence. Environment and Planning A, 34(6), 981-999.

Mulder, C. H., \& Hooimeijer, P. (1999). Residential relocations in the life course. In L. Van Wissen \& P. Dykstra (Eds.), Population issues (pp. 159-186): Springer.

Mulder, C. H., \& Wagner, M. (1993). Migration and marriage in the life course: a method for studying synchronized events. European Journal of Population/Revue européenne de Démographie, 9(1), 55-76.

Mulder, C. H., \& Wagner, M. (2010). Union dissolution and mobility: who moves from the family home after separation? Journal of Marriage and Family, 72(5), 1263-1273.

Niedomysl, T. (2011). How migration motives change over migration distance: evidence on variation across socio-economic and demographic groups. Regional studies, 45(6), 843855.

Neugarten, B., Moore, J., \& Lowe, J. (1965). Age norms, age constraints, and adult socialization. American journal of Sociology, 70(6), 710-717.

Office for National Statistics. (2016). Geography Glossary. Local Authority Disctrict (LAD).

Patiniotis, J., \& Holdsworth, C. (2005). 'Seize that chance!'Leaving home and transitions to higher education. Journal of youth studies, 8(1), 81-95.

Pronzato, C. (2010). Family histories from BHPS. British Household Panel Survey Consolidated Marital, Cohabitational and Fertility Histories, UK Data Archive Study Number 5629.

Putter, H., Fiocco, M., \& Geskus, R. (2007). Tutorial in biostatistics: competing risks and multi-state models. Statistics in medicine, 26(11), 2389-2430.

Rabe, B., \& Taylor, M. (2010). Residential mobility, quality of neighbourhood and life course events. Journal of the Royal Statistical Society: Series A (Statistics in Society), 173(3), 531-555.

Sage, J., Evandrou, M., \& Falkingham, J. (2013). Onwards or Homewards? Complex Graduate Migration Pathways, Well-being, and the 'Parental Safety Net'. Population, space and place, 19(6), 738-755.

Settersten, R., \& Ray, B. (2010). What's going on with young people today? The long and twisting path to adulthood. The future of children, 20(1), 19-41.

Shanahan, M. J. (2000). Pathways to adulthood in changing societies: Variability and mechanisms in life course perspective. Annual review of sociology, 667-692.

Sheller, M., \& Urry, J. (2006). The new mobilities paradigm. Environment and Planning A, 38(2), 207-226.

Smith, D. P., \& Finney, N. (2015). Hosuing and Internal Migration. In D. P. Smith, N. Finney, K. Halfacree, \& N. Walford (Eds.), Internal Migration (pp. 81-98). Farnham: Ashgate.

Smith, D. P., \& Holt, L. (2007). Studentification and 'apprentice'gentrifiers within Britain's provincial towns and cities: extending the meaning of gentrification. Environment and Planning A, 39(1), 142-161.

Smith, D. P., \& Sage, J. (2014). The regional migration of young adults in England and Wales (2002-2008): a 'conveyor-belt' of population redistribution? Children's Geographies, 12(1), 102-117.

Smits, J., Mulder, C. H., \& Hooimeijer, P. (2003). Changing gender roles, shifting power balance and long-distance migration of couples. Urban studies, 40(3), 603-613.

Sobotka, T., \& Toulemon, L. (2008). Overview Chapter 4: Changing family and partnership behaviour: Common trends and persistent diversity across Europe. Demographic research, 19(6), 85-138. 
Stone, J., Berrington, A., \& Falkingham, J. (2011). The changing determinants of UK young adults' living arrangements. Demographic Research, 25(20), 629-666.

Stone, J., Berrington, A., \& Falkingham, J. (2014). Gender, turning points, and boomerangs: Returning home in young adulthood in Great Britain. Demography, 51(1), 257-276.

Thomson, E. (2014). Family complexity in Europe. Annals of the American Academy of Political and Social Science, 654, 245-258.

Thulin, E., \& Vilhelmson B. (2014). Virtual practices and migration plans: a qualitative study of urban young adults. Population, Space and Place, 20, 389-401.

Vilhelmson, B., \& Thulin, E. (2013). Does Internet encourage people to move? Investigating Swedish young adults' internal migration experiences and plans. Geoforum, 47, 209216.

Vilhelmson, B., \& Thulin, E. (2016). Environment as a Multifaceted Migration Motive: Meanings and Interpretations Among a Group of Young Adults in Sweden. Population, Space and Place, 22, 276-287.

Walford, N., \& Stockdale, A. (2015). Lifestyle and Internal Migration. In D. P. Smith, N. Finney, K. Halfacree, \& N. Walford (Eds.), Internal Migration (pp. 99-111). Farnham: Ashgate.

Whittington, L., \& Peters, E. (1996). Economic incentives for financial and residential independence. Demography, 33(1), 82-97.

Winkler-Dworak, M., \& Toulemon, L. (2007). Gender differences in the transition to adulthood in France: is there convergence over the recent period? European Journal of Population/Revue européenne de Démographie, 23(3-4), 273-314. 


\section{Tables and figures}

Table 1. Occurrence and exposure table by order of moves

\begin{tabular}{lrrrrrrr}
\hline Move order & Person-years & Moves & Rate & $\mathbf{2 5 \%}$ & $\mathbf{5 0 \%}$ & $\mathbf{7 5 \%}$ & \\
\hline 1st move & $12,108.48$ & 1,358 & 0.112 & 19.3 & 21.8 & 26 & (age in years) \\
2nd move & $2,941.85$ & 900 & 0.306 & 1 & 1.9 & 4.2 & (time since $1^{\text {st }}$ \\
3rd+moves & $4,660.26$ & 1,470 & 0.315 & & & move) \\
\hline Total & $19,710.58$ & 3,728 & 0.189 & & & \\
\hline
\end{tabular}

Source: BHPS waves 1-18; own calculations

Table 2. Median age at first move by cohort and gender

\begin{tabular}{lllcc}
\hline \multirow{2}{*}{ Cohort } & Gender & Age & $\begin{array}{c}\text { Median age for both } \\
\text { genders }\end{array}$ & Gender gap \\
\hline $1974-1979$ & females & 20.9 & 21.4 & 2.2 \\
& males & 22.1 & 21.6 & 2.1 \\
\hline $1980-1984$ & females & 20.8 & 22.5 & 2 \\
& males & 22.9 & & \multirow{2}{*}{1.9} \\
\hline Overall & females & 21.3 & 21.8 & \\
& males & 23.3 & & 2.9 \\
\hline
\end{tabular}

Source: BHPS waves 1-18; own calculations

Figure 1. Hazard rates for all moves by cohort and order of move

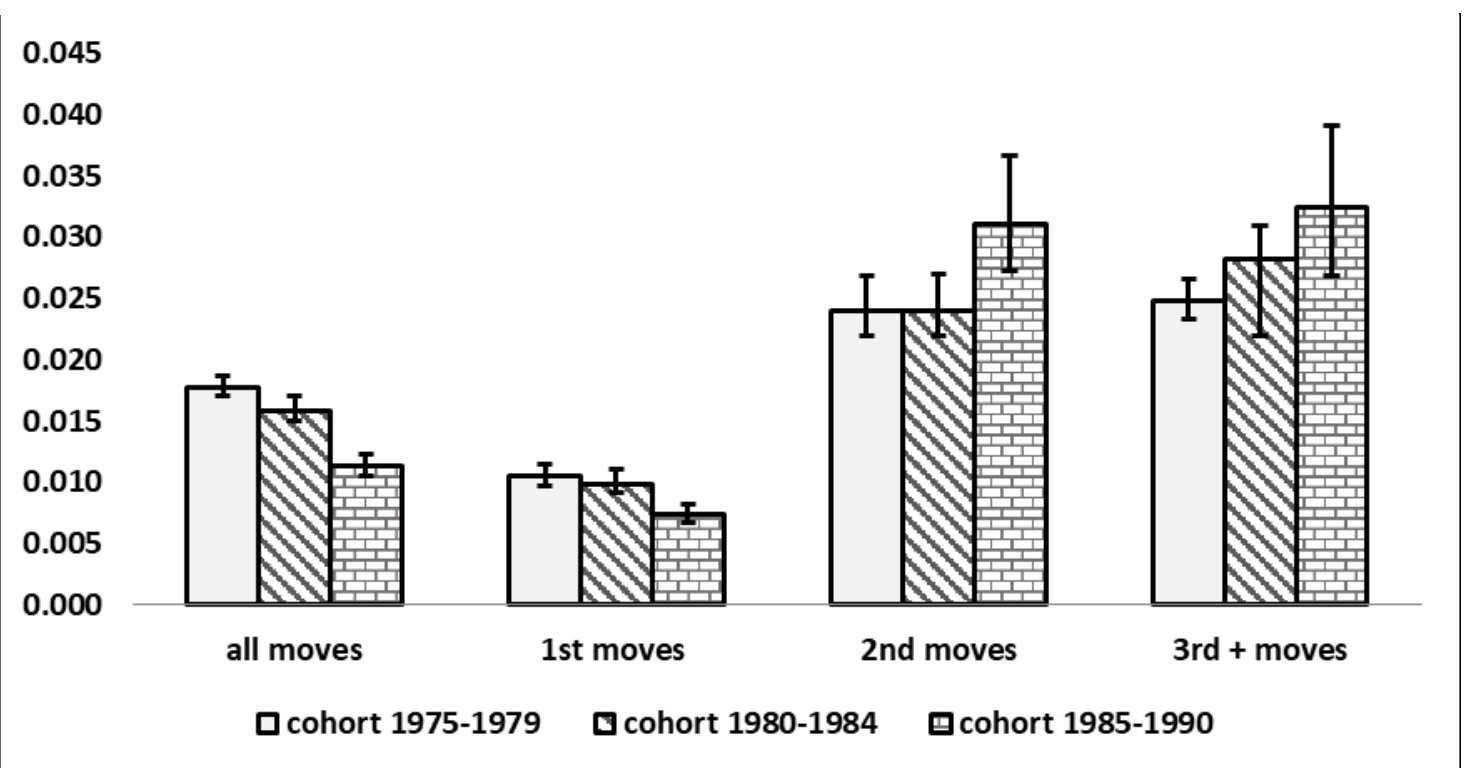

Source: BHPS waves 1-18; own calculations 
Figure 2. Relative hazard of moving by order and type of move and cohort

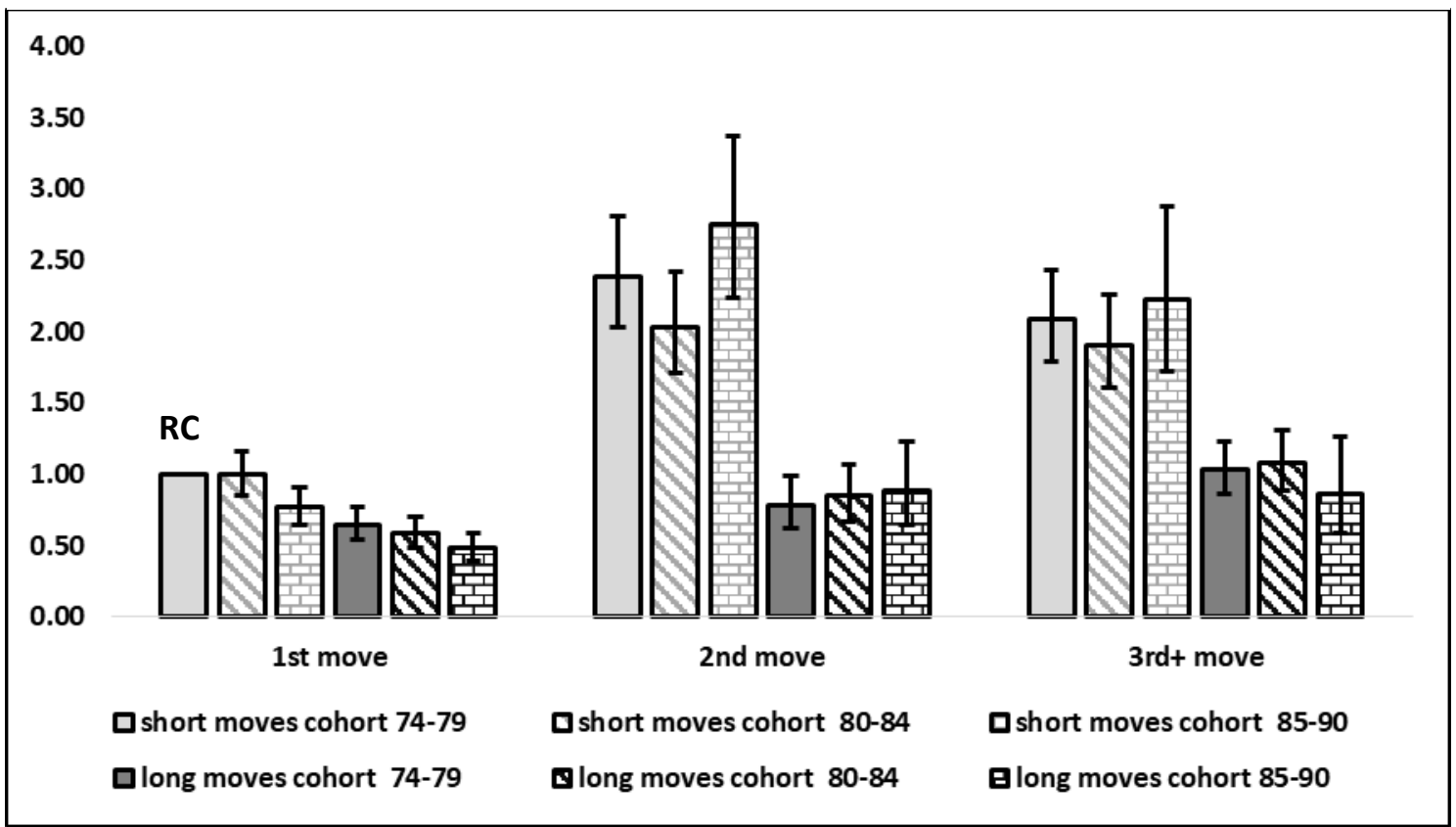

Source: BHPS waves 1-18; own calculations

Note: The model is controlled for gender, partnership and economic activity status, parental SES, education level, area type. Young people from the 1974-79 birth cohort moving short distance first time were chosen as a reference category.

Figure 3. Relative hazard of moving by order and type of move and gender

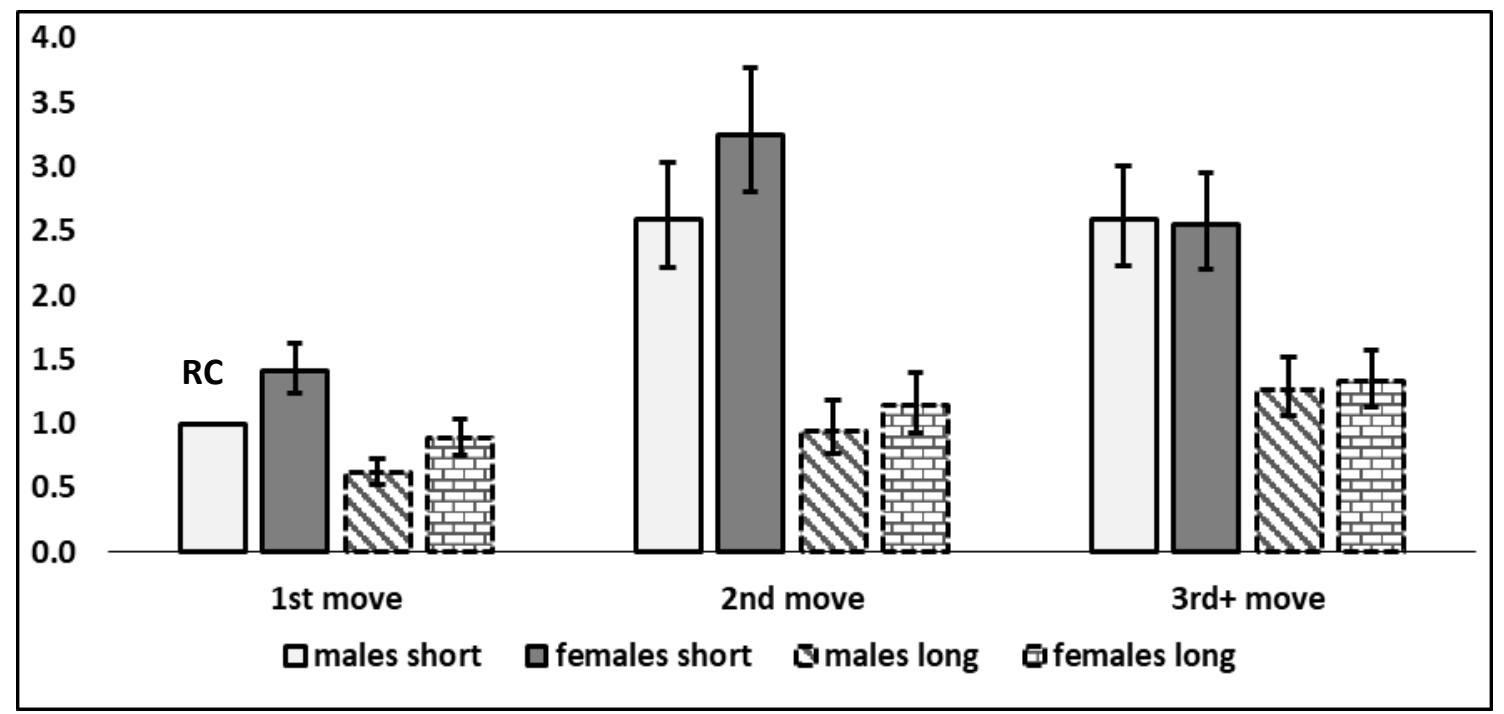

Source: BHPS waves 1-18; own calculations

Note: The model is controlled for cohort, partnership and economic activity status, parental SES, education level, area type. Males moving short distance first time were chosen as a reference category. 
Figure 4. Standardised cohort differences in $1^{\text {st }}$ short- and long- distance moves (by educational level, partnership and economic activity status status)

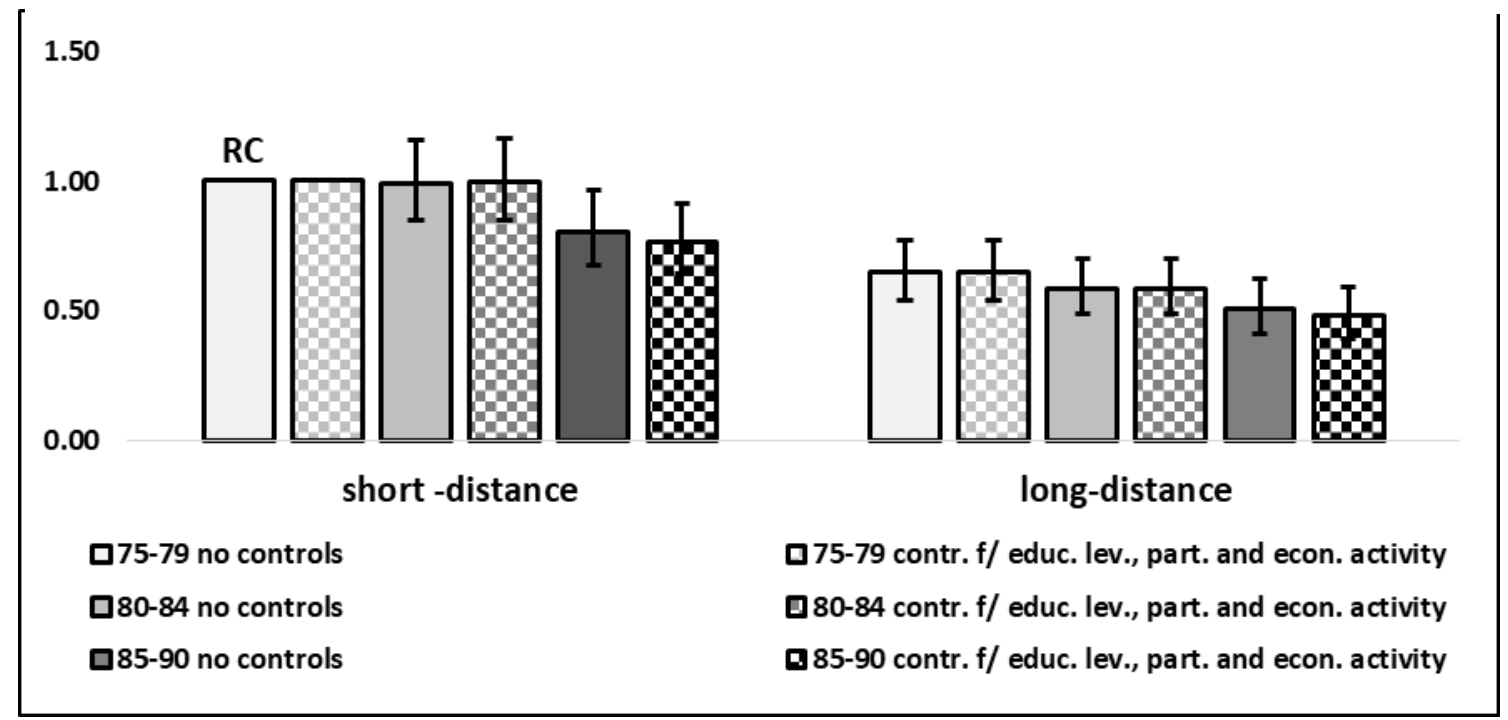

Source: BHPS waves 1-18; own calculations. Note: Young people from the 1974-79 birth cohort moving short distance first time were chosen as a reference category.

Figure 5. Standardised gender differences in $1^{\text {st }}$ short- and long- distance moves (by educational level, partnership and economic activity status status)

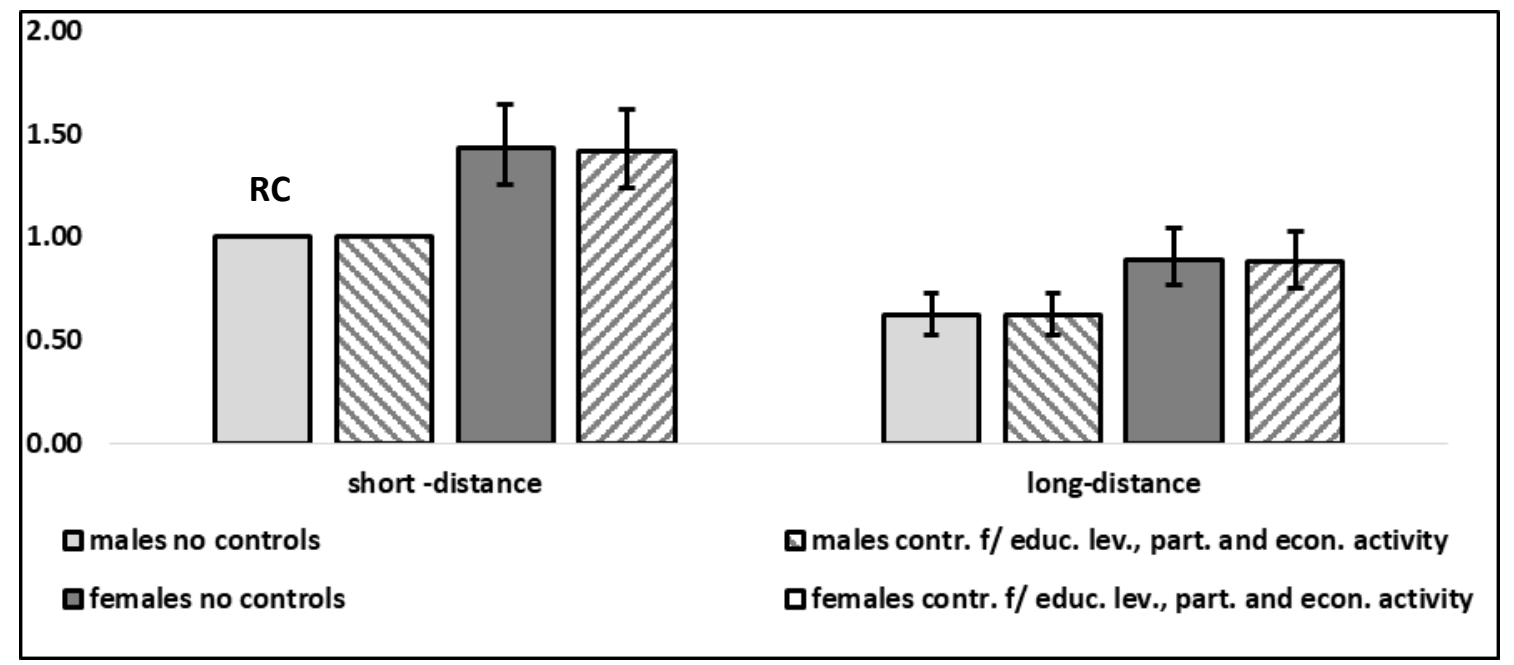

Source: BHPS waves 1-18; own calculations. Note: Males moving short distance first time were chosen as a reference category. 
Table 3. Hazard ratios for all moves and by order of move

\begin{tabular}{|c|c|c|c|c|c|c|c|c|}
\hline \multirow{2}{*}{ Variables } & \multicolumn{2}{|c|}{ All moves } & \multicolumn{2}{|c|}{ First moves } & \multicolumn{2}{|c|}{$\begin{array}{l}\text { Second } \\
\text { moves }\end{array}$} & \multicolumn{2}{|c|}{$\begin{array}{c}\text { Third and higher } \\
\text { order moves }\end{array}$} \\
\hline & $\begin{array}{l}\text { Haz. } \\
\text { Ratio }\end{array}$ & Sig & $\begin{array}{l}\text { Haz. } \\
\text { Ratio }\end{array}$ & Sig & $\begin{array}{l}\text { Haz. } \\
\text { Ratio }\end{array}$ & Sig & $\begin{array}{l}\text { Haz. } \\
\text { Ratio }\end{array}$ & Sig \\
\hline Age & \multicolumn{4}{|c|}{ Baseline hazards } & & & & \\
\hline $16-17$ & 0.002 & $* * *$ & 0.002 & $* * *$ & & & & \\
\hline $18-20$ & 0.005 & $* * *$ & 0.005 & $* * *$ & & & & \\
\hline $21-23$ & 0.005 & $* * *$ & 0.004 & $* * *$ & & & & \\
\hline $24-26$ & 0.004 & $* * *$ & 0.004 & $* * *$ & & & & \\
\hline $27+$ & 0.003 & $* * *$ & 0.003 & $* * *$ & & & & \\
\hline Time since previous move & & & & & \multirow{2}{*}{\multicolumn{4}{|c|}{ Baseline hazards }} \\
\hline First move & 1 & & & & & & & \\
\hline $0-1$ years & 1.79 & & & & 0.009 & $* * *$ & 0.012 & $* * *$ \\
\hline $1-3$ years & 2.54 & $* * *$ & & & 0.012 & $* * *$ & 0.018 & $* * *$ \\
\hline 3-5 years & 1.90 & $* * *$ & & & 0.009 & $* * *$ & 0.013 & $* * *$ \\
\hline $5+$ years & 1.55 & $* * *$ & & & 0.006 & $* * *$ & 0.011 & $* * *$ \\
\hline Adjustment for the $3^{\text {rd }}+$ moves & 0.97 & & & & & & & \\
\hline Sex & & & & & & & & \\
\hline Males & 1 & & 1 & & 1 & & 1 & \\
\hline Females & 1.20 & $* * *$ & 1.36 & $* * *$ & 1.23 & $* *$ & 1.04 & \\
\hline \multicolumn{9}{|l|}{ Cohort } \\
\hline 1974-1979 & 1 & & 1 & & 1 & & 1 & \\
\hline $1980-1984$ & 0.94 & & 0.97 & & 0.95 & & 1.06 & \\
\hline $1985-1990$ & 0.87 & $* *$ & 0.75 & $* * *$ & 1.15 & & 1.21 & $*$ \\
\hline \multicolumn{9}{|l|}{ Parental occupational class } \\
\hline Service class & 1 & & 1 & & 1 & & 1 & \\
\hline Intermediate class & 0.87 & $* *$ & 0.86 & $* *$ & 0.77 & $* *$ & 0.86 & $*$ \\
\hline Working class & 0.93 & & 0.90 & & 0.97 & & 0.86 & $*$ \\
\hline Missing & 0.92 & & 0.96 & & 0.81 & & 0.88 & \\
\hline \multicolumn{9}{|l|}{ Partnership status } \\
\hline Single & 1 & & 1 & & 1 & & 1 & \\
\hline Cohabitating & 0.97 & & 4.22 & $* * *$ & 1.26 & & 0.88 & \\
\hline Married & 0.79 & $* *$ & 2.82 & $* * *$ & 1.03 & & 0.67 & $*$ \\
\hline Separated & 1.49 & $* * *$ & 1.67 & $* *$ & 1.09 & & 0.94 & \\
\hline \multicolumn{9}{|l|}{ Educational level } \\
\hline Compulsory school education & 1 & & 1 & & 1 & & 1 & \\
\hline Post-compulsory education & 1.37 & $* * *$ & 1.65 & $* * *$ & 1.16 & & 1.01 & \\
\hline Bachelor's degree or higher & 1.85 & $* * *$ & 2.27 & $* * *$ & 3.54 & $*$ & 0.90 & \\
\hline \multicolumn{9}{|l|}{ Economic Activity Status } \\
\hline Full-time employed & 1 & & 1 & & 1 & & 1 & \\
\hline Part-time employed & 0.81 & $* *$ & 0.96 & & 1.02 & & 0.85 & \\
\hline Full-time student & 1.15 & $* *$ & 1.22 & $* *$ & 1.12 & & 1.27 & $* *$ \\
\hline Unemployed & 1.25 & $* * *$ & 1.40 & $* *$ & 1.24 & & 0.95 & \\
\hline Others/Missing & 0.91 & & 0.87 & & 1.00 & & 0.76 & $*$ \\
\hline \multicolumn{9}{|l|}{ Area type } \\
\hline London & 1 & & 1 & & & & 1 & \\
\hline Other urban & 1.31 & $* * *$ & 1.50 & $* * *$ & 1.19 & & 1.14 & \\
\hline Small towns and rural areas & 1.36 & $* * *$ & 1.56 & $* * *$ & 1.22 & $*$ & 1.15 & $*$ \\
\hline \multicolumn{9}{|l|}{ Type of move } \\
\hline Short-distance & 1 & & & & & & 1 & \\
\hline Long-distance & 0.51 & $* * *$ & & & & & 0.51 & $* * *$ \\
\hline
\end{tabular}

Source: BHPS waves 1-18; own calculations. Note: ${ }^{*} p<0.05,{ }^{* *} p<0.01,{ }^{* * *} p<0.001$ 


\section{Appendix}

Table 4A. Person-months at risk and number of events by covariates

\begin{tabular}{|c|c|c|c|c|}
\hline Covariate & $\begin{array}{r}\text { Risk-time } \\
\text { (person-years) }\end{array}$ & $\%$ & Events & $\%$ \\
\hline $\begin{array}{l}\text { Order of move } \\
1^{\text {st }} \text { move } \\
2^{\text {nd }} \text { move } \\
3^{\text {rd }}+\text { move }\end{array}$ & $\begin{array}{r}12108.48 \\
2941.85 \\
4660.26\end{array}$ & $\begin{array}{l}61.4 \\
14.9 \\
23.6\end{array}$ & $\begin{array}{r}1358 \\
900 \\
1470\end{array}$ & $\begin{array}{l}36.4 \\
24.1 \\
39.4\end{array}$ \\
\hline $\begin{array}{l}\text { Type of move } \\
\text { Short-distance } \\
\text { Long-distance }\end{array}$ & & & $\begin{array}{l}2472 \\
1253\end{array}$ & $\begin{array}{l}66.3 \\
33.7\end{array}$ \\
\hline $\begin{array}{l}\text { Cohort } \\
1974-1979 \\
1980-1984 \\
1985-1990 \\
\end{array}$ & $\begin{array}{l}8570.08 \\
6518.75 \\
4621.75 \\
\end{array}$ & $\begin{array}{l}43.5 \\
33.1 \\
23.4 \\
\end{array}$ & $\begin{array}{r}1834 \\
1264 \\
630 \\
\end{array}$ & $\begin{array}{l}49.2 \\
33.9 \\
16.9 \\
\end{array}$ \\
\hline $\begin{array}{l}\text { Sex } \\
\text { Males } \\
\text { Females } \\
\end{array}$ & $\begin{array}{r}10050.75 \\
9659.83 \\
\end{array}$ & $\begin{array}{l}51 \\
49 \\
\end{array}$ & $\begin{array}{l}1669 \\
2059 \\
\end{array}$ & $\begin{array}{l}44.8 \\
55.2 \\
\end{array}$ \\
\hline $\begin{array}{l}\text { Parental occupational class } \\
\text { Service class } \\
\text { Intermediate class } \\
\text { Working class } \\
\text { Missings }\end{array}$ & $\begin{array}{l}7354.92 \\
5608.33 \\
4990.58 \\
1756.75 \\
\end{array}$ & $\begin{array}{r}37.3 \\
28.5 \\
25.3 \\
8.9 \\
\end{array}$ & $\begin{array}{r}1642 \\
924 \\
850 \\
312 \\
\end{array}$ & $\begin{array}{r}44 \\
24.8 \\
22.8 \\
8.4\end{array}$ \\
\hline $\begin{array}{l}\text { Educational level } \\
\text { Compulsory school education } \\
\text { Post-compulsory education } \\
\text { Bachelor's degree or higher }\end{array}$ & $\begin{array}{r}12238.17 \\
5761.08 \\
1711.33\end{array}$ & $\begin{array}{r}62.1 \\
29.2 \\
8.7\end{array}$ & $\begin{array}{r}1601 \\
1476 \\
651\end{array}$ & $\begin{array}{l}42.9 \\
39.6 \\
17.5\end{array}$ \\
\hline $\begin{array}{l}\text { Partnership status } \\
\text { Single } \\
\text { Cohabitating } \\
\text { Married } \\
\text { Separated }\end{array}$ & $\begin{array}{r}15544.36 \\
2196.46 \\
1192.95 \\
776.82\end{array}$ & $\begin{array}{r}78.9 \\
11.1 \\
6.1 \\
3.9\end{array}$ & $\begin{array}{r}2579 \\
576 \\
238 \\
335\end{array}$ & $\begin{array}{r}69.2 \\
15.5 \\
6.4 \\
9\end{array}$ \\
\hline $\begin{array}{l}\text { Economic Activity Status } \\
\text { Full-time employed } \\
\text { Part-time employed } \\
\text { Full-time student } \\
\text { Unemployed } \\
\text { Others/Missings }\end{array}$ & $\begin{array}{r}8159.92 \\
1473.42 \\
6304.08 \\
1441 \\
2332.17\end{array}$ & $\begin{array}{r}41.4 \\
7.5 \\
32 \\
7.3 \\
11.8\end{array}$ & $\begin{array}{r}1785 \\
240 \\
1035 \\
327 \\
341\end{array}$ & $\begin{array}{r}47.9 \\
6.4 \\
27.8 \\
8.8 \\
9.1\end{array}$ \\
\hline $\begin{array}{l}\text { Area type of residence } \\
\text { London } \\
\text { Other urban } \\
\text { Small towns and rural areas }\end{array}$ & $\begin{array}{l}2711.81 \\
7917.59 \\
9081.18\end{array}$ & $\begin{array}{l}13.7 \\
40.2 \\
46.1\end{array}$ & $\begin{array}{r}429 \\
1537 \\
1762\end{array}$ & $\begin{array}{l}11.51 \\
41.23 \\
47.26\end{array}$ \\
\hline Total & 19710.58 & 100 & 3728 & 100 \\
\hline
\end{tabular}

Source: BHPS waves 1-18; own calculations 
Figure 7A. Standardised cohort differences in $2^{\text {nd }}$ and $3+$ short-distance moves (by educational level and partnership status)

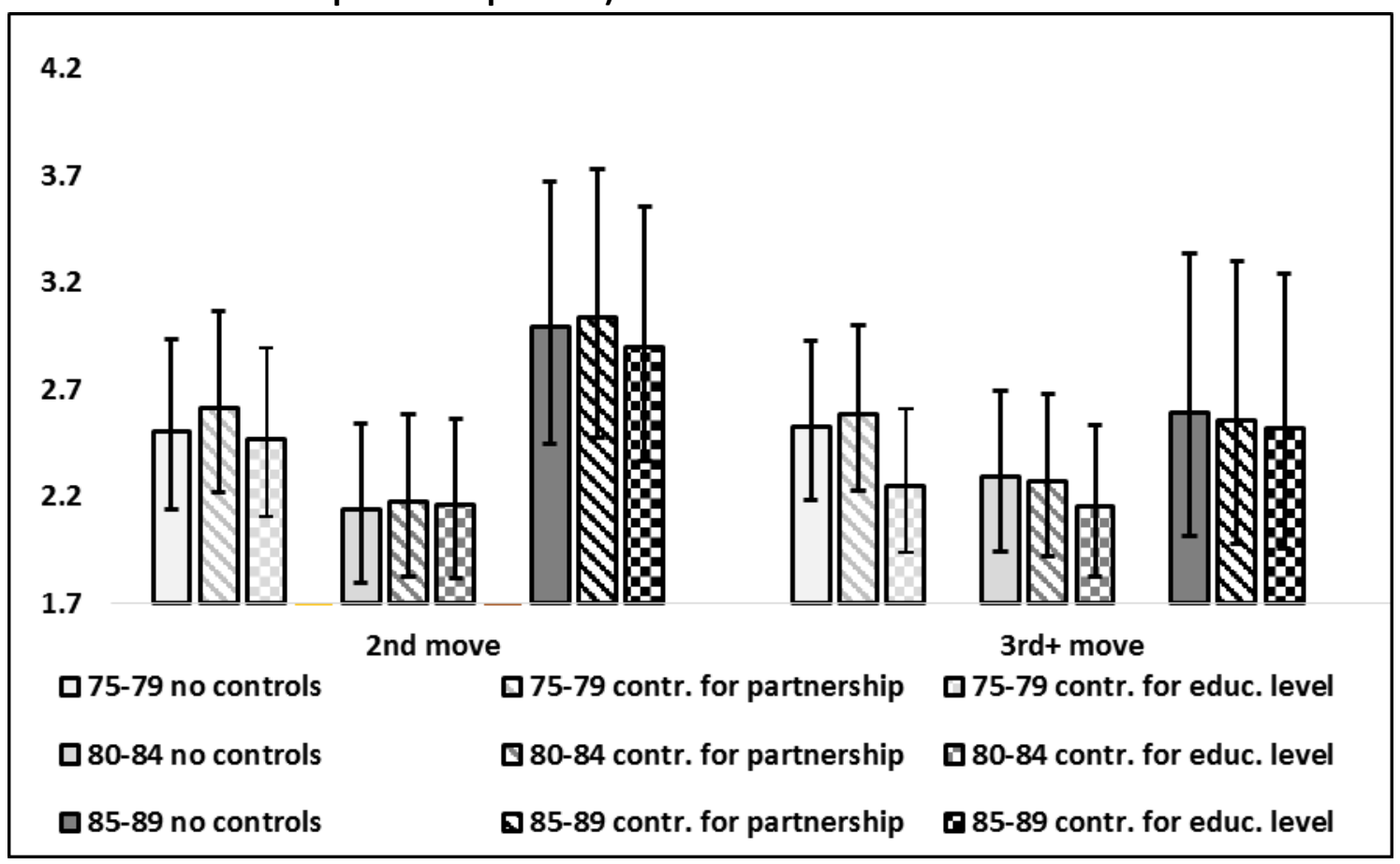

Source: BHPS waves 1-18; own calculations

Note: $1^{\text {st }}$ moves for the birth cohort $1975-79$ is the reference category.

Figure 6A. Standardised gender differences in $2^{\text {nd }}$ and $3^{\text {rd }}+$ short-distance moves (by educational level and partnership status)

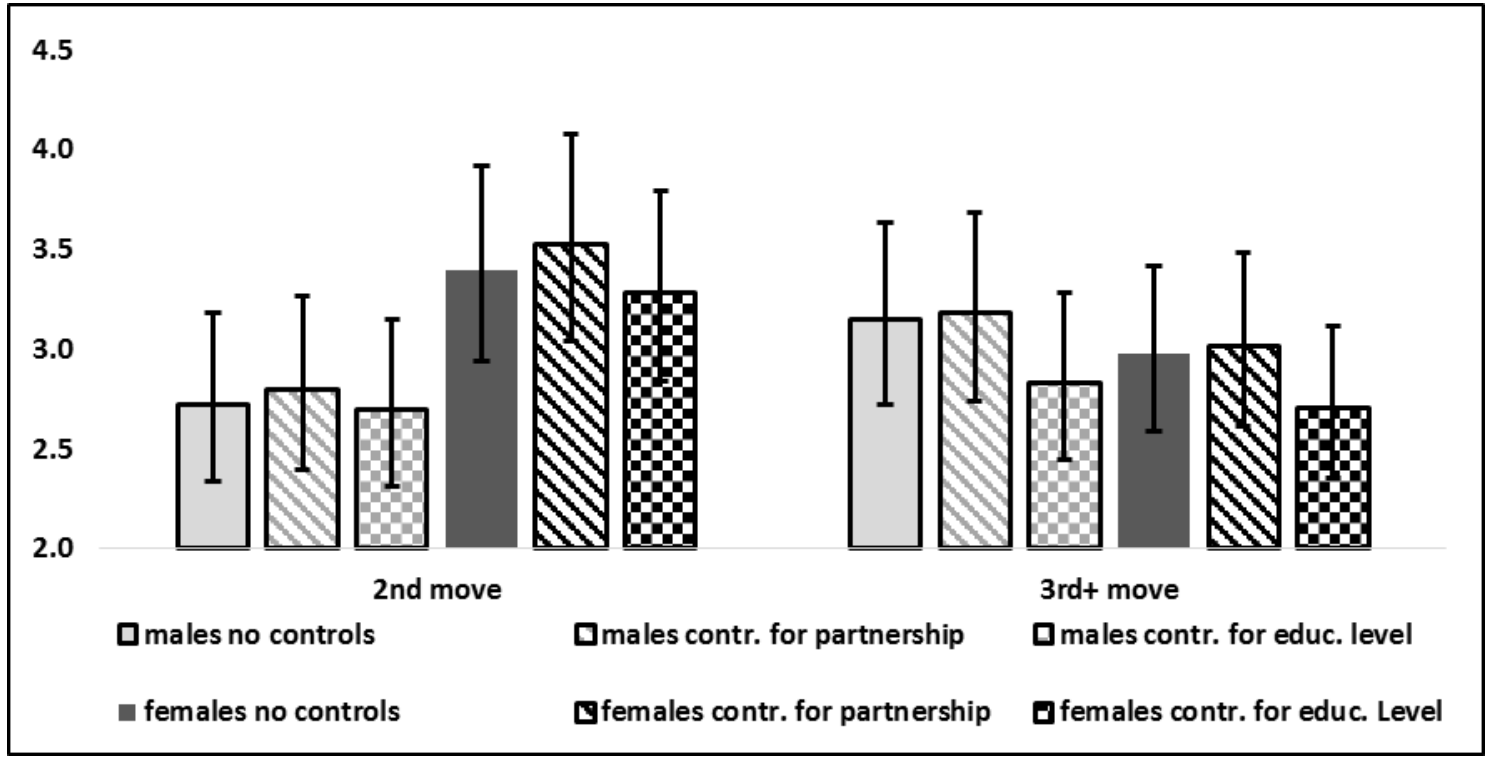

Source: BHPS waves 1-18; own calculations

Note: $1^{\text {st }}$ moves for males is the reference category. 